\title{
Current Mechanistic Concepts in Ischemia and Reperfusion Injury
}

\author{
Meng-Yu Wu $u^{a, b}$ Giou-Teng Yianga,b Wan-Ting Liaoc,d Andy Po-Yi Tsaie \\ Yeung-Leung Cheng ${ }^{f}$ Pei-Wen Cheng ${ }^{g, h} \quad$ Chia-Ying Li, ${ }^{i, j} \quad$ Chia-Jung Lik
}

aDepartment of Emergency Medicine, Taipei Tzu Chi Hospital, Buddhist Tzu Chi Medical Foundation, New Taipei; bDepartment of Emergency Medicine, School of Medicine, Tzu Chi University, Hualien; 'Chinese Medicine Department, Show Chwan Memorial Hospital, Changhua; 'Graduate Institute of Chinese Medicine, China Medical University, Taichung; ${ }^{~}$ Department of Medical Research, Buddhist Tzu Chi General Hospital, Hualien; 'Division of Thoracic Surgery, Department of Surgery, Taipei Tzu Chi Hospital, Buddhist Tzu Chi Medical Foundation, New Taipei City and School of Surgery, Tzu Chi University, Hualien; ${ }^{9}$ Yuh-Ing Junior College of Health Care \& Management, Kaohsiung; ' $D$ Department of Medical Education and Research, Kaohsiung Veterans General Hospital, Kaohsiung; iSchool of Medicine, College of Medicine, Fu Jen Catholic University, New Taipei City; 'Department of Surgery, Show Chwan Memorial Hospital, Changhua; kesearch Assistant Center, Show Chwan Memorial Hospital, Changhua, Taiwan

\section{Key Words}

Ischemia-reperfusion injury $•$ Autophagy $・$ Mitoptosis $・$ Necroptosis $・$ Apoptosis

\begin{abstract}
Ischemia-reperfusion injury is associated with serious clinical manifestations, including myocardial hibernation, acute heart failure, cerebral dysfunction, gastrointestinal dysfunction, systemic inflammatory response syndrome, and multiple organ dysfunction syndrome. Ischemia-reperfusion injury is a critical medical condition that poses an important therapeutic challenge for physicians. In this review article, we present recent advances focusing on the basic pathophysiology of ischemia-reperfusion injury, especially the involvement of reactive oxygen species and cell death pathways. The involvement of the NADPH oxidase system, nitric oxide synthase system, and xanthine oxidase system are also described. When the blood supply is re-established after prolonged ischemia, local inflammation and ROS production increase, leading to secondary injury. Cell damage induced by prolonged ischemia-reperfusion injury may lead to apoptosis, autophagy, necrosis, and necroptosis. We highlight the latest mechanistic insights into reperfusion-injury-induced cell death via these different processes. The interlinked signaling pathways of cell death could offer new targets for therapeutic approaches. Treatment approaches for ischemia-reperfusion injury are also reviewed. We believe that understanding the pathophysiology ischemia-reperfusion injury will enable the development of novel treatment interventions.

Chia-Ying Li and Chia-Jung Li
Department of Surgery, Show Chwan Memorial Hospital, Changhua Research Assistant Center, Show Chwan Memorial Hospital, Changhua (Taiwan) E-Mailb86401115@ntu.edu.tw/nigel6761@gmail.com

\section{KARGER}




\section{Cellular Physiology Cell Physiol Biochem 2018;46:1650-1667 and Biochemistry Publisned onIIne:April 25, $2018 \quad \begin{aligned} & \text { DO } 2018 \text { The Author(s). Published by S. Karger AG, Basel } \\ & \text { www.karger.com/cpb }\end{aligned}$}

Wu et al.: Cellular Mechanisms of I/R Injury

\section{Introduction}

Ischemia-reperfusion injury is a critical condition for which physicians must control cell damage and preserve organ function. Ischemia is defined as the hypoperfusion of tissues. Several conditions, such as sepsis, acute coronary syndrome, organ transplantation, and limb injury, may cause tissue hypoperfusion. Previous studies have focused on reducing the time of hypoperfusion to preserve organ function. For sepsis, the Surviving Sepsis Campaign guidelines recommend early goal-directed therapy for timely resuscitation, including early antibiotic treatment and resuscitation with adequate fluids and vasopressors to reduce peripheral tissue hypoperfusion [1-8]. For acute coronary syndrome, the ACCF/AHA/SCAI guidelines recommend early revascularization to control myocardial injury [9]. Similar recommendations have been made for organ transplantation and limb injury. However, clinical outcomes after restoration of blood flow to ischemic tissue are not optimal. Recent studies have demonstrated that reperfusion has the potential to induce subsequent injury in ischemic tissue, a phenomenon termed ischemia-reperfusion injury. The subsequent injury induced by ischemia-reperfusion injury presents a challenge for physicians to preserve organ and neurogenic function. Despite basic and clinical research efforts, a detailed mechanism of ischemia-reperfusion injury has not been described. We believe that elucidating the pathogenesis of this condition could provide a strong foundation for the development of new therapeutic interventions. This article provides an overview of advances in ischemiareperfusion injury research and summarizes our current understanding of related mechanisms and potential targets for potential therapeutic intervention.

\section{Mechanism of ischemia-reperfusion injury}

Several physiological mechanisms promote ischemia and lead to hypoxia and hypoperfusion, including atherosclerosis and acute myocardial infarction $[10,11]$. The obstruction of arterial blood flow causes hypoxia and leads to dysfunction of the electron transport chain in mitochondria. Decreasing ATP production in mitochondria induces anaerobic metabolism, dysfunction of sodium-potassium pumps, and detachment of

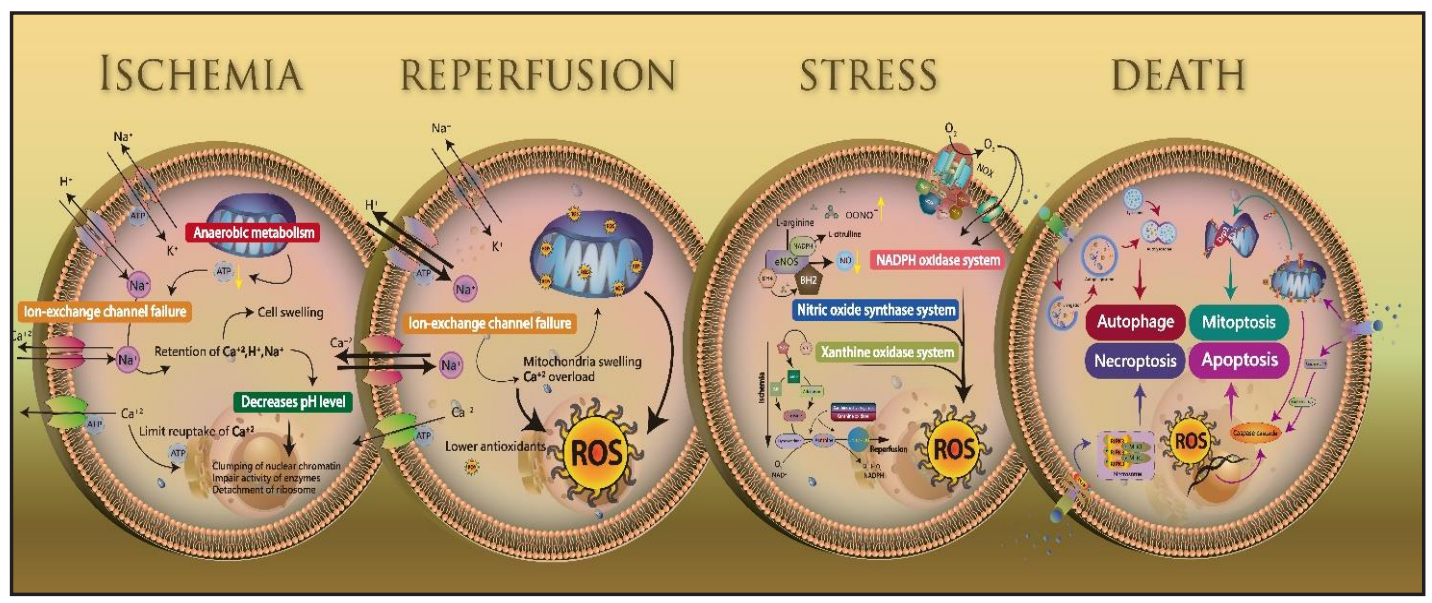

Fig. 1. Overview of the mechanism of ischemia-reperfusion injury. The ischemic state induces anaerobic metabolism, leading to a lower level of ATP production and failure of ion-exchange channels. Failure of ionexchange channels leads to cell swelling and impaired enzymatic activity in the cytoplasm. Mitochondrial damage and electrolyte imbalance in the reperfusion state promote oxidative stress from three major systems: the NADPH oxidase system, nitric oxide synthase system, and xanthine oxidase system. ROS retention induces cell damage, leading to cell death via four pathways: autophagy, mitoptosis, necrosis and necroptosis, and apoptosis.

\section{KARGER}




\section{Cellular Physiology Cell Physiol Biochem 2018;46:1650-1667 \begin{tabular}{l|l} 
DOI: 10.1159/000489241 & and Biochemistry 2018 The Author(s). Published by S. Karger AG, Basel \\
wublished online: April 25, 2018 & $\begin{array}{l}\text { wwrger.com/cpb } \\
\text { and }\end{array}$
\end{tabular}}

Wu et al.: Cellular Mechanisms of I/R Injury

ribosomes. Anaerobic metabolism produces a lower level of adenosine triphosphate (ATP) and antioxidative agents in cells. Moreover, the retention of lactic acid may lead to metabolic acidosis. In addition, there may be failure of sodium-potassium pumps (Na+-K+-ATPase pumps) and calcium pumps (Ca2+-ATPase pumps) on the cell surface. The failure of $\mathrm{Na}+-\mathrm{K}+-$ ATPase pumps causes retention of sodium in cells and potassium out of cells. A higher level of sodium in cells decreases the activity of sodium-hydrogen exchanger pumps $(\mathrm{Na}+-\mathrm{H}+$ pumps). Calcium pumps (Ca2+-ATPase pumps) on the endoplasmic reticulum also become dysfunctional, which limits calcium reuptake. In cells, the accumulation of hydrogen, sodium and calcium ions causes hyperosmolarity, which leads to water flow into the cytoplasm and cell swelling. The retention of hydrogen decreases cellular $\mathrm{pH}$, leading to impaired enzyme activity and clumping of nuclear chromatin. The detachment of ribosomes decreases protein synthesis. After the reperfusion stage, restoring blood flow to ischemic tissue provides oxygen via red blood cells. In parallel, the generation of reactive oxygen species (ROS) increases due

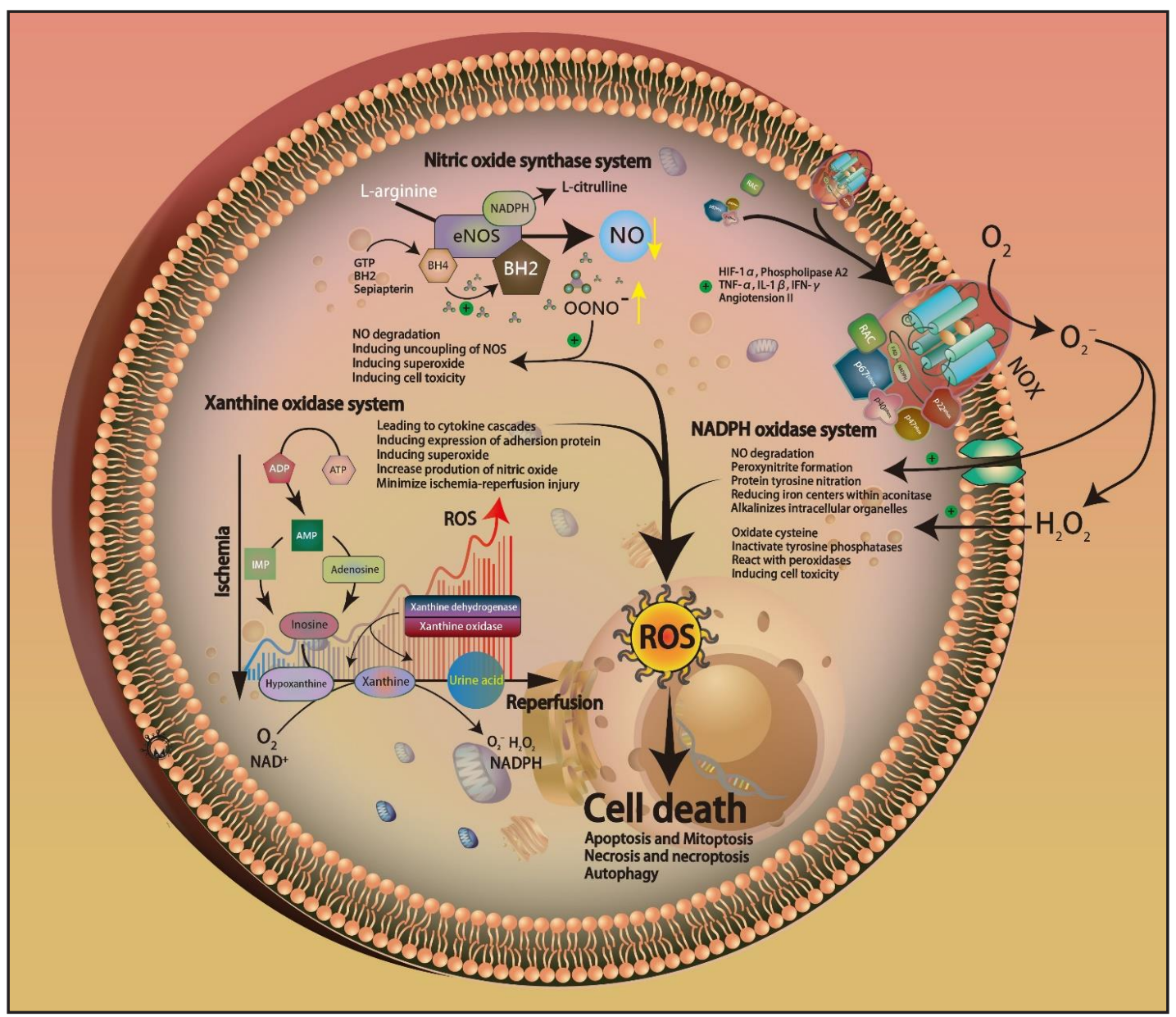

Fig. 2. Mechanism of ROS in ischemia-reperfusion injury. The xanthine oxidase system induces ROS production by oxidizing hypoxanthine to xanthine and xanthine to uric acid. Initially, ATP is converted to inosine from IMP and adenosine, then into hypoxanthine. In the ischemic state, xanthine dehydrogenase is shifted to xanthine oxidoreductase due to a lower ATP level, inducing the formation of ROS during hypoxanthine conversion to urine acid. NOX enzymes produce superoxide and hydrogen peroxide in ischemia-reperfusion injury via the activation of HIF- $1 \alpha$, phospholipase A2, TNF- $\alpha$, IL-1 $\beta$, IFN- $\gamma$, and angiotension II. Superoxides pass through the cell membrane via channels due to a negative charge. Hydrogen peroxide directly enters the cytoplasm and causes cell damage. In the hypoxic state, oxidative stress oxidizes BH4 into BH2 and induces the uncoupling of NOS. NOS uncoupling produces ROS, which induces ischemia-reperfusion injury leading to cell death. 
to a lower concentration of antioxidative agents in ischemic cells. ROS cause oxidative stress that promotes endothelial dysfunction, DNA damage, and local inflammatory responses (Fig. 1). Inflammatory cascades and oxidative stress may subsequently induce a cytokine storm, resulting in cell death caused by damage to cellular structures [12]. The reperfusion stage is dynamic and may persist for several days. Understanding the detailed mechanism of ischemia-reperfusion injury may provide a strong foundation not only for novel therapeutic opportunities, but also for injury prevention.

\section{The role of oxidative stress in ischemia-reperfusion injury}

Oxidative stress can be produced from enzymatic sources and non-enzymatic sources. Common enzymatic sources include the xanthine oxidase system, NADPH oxidase system, mitochondrial electron transport chain, and uncoupled nitric oxide synthase (NOS) system. Non-enzymatic sources are a minor source of oxidative stress, and include hemoglobin and myoglobin, especially in extremity injury. The xanthine oxidase system, NADPH oxidase system, and mitochondrial electron transport chain are broadly implicated in oxidative stress in several organs, including the intestine, lung, heart, brain, muscle, liver, pancreas, stomach, and kidney [13]. NOS is a major oxidative stress factor in the liver, heart, and aortic endothelial cells [14-16]. These enzyme systems are discussed in detail in the following sections.

\section{Mechanisms of xanthine oxidase induction of oxidative stress in ischemia- reperfusion injury}

Xanthine oxidoreductases are complex molybdoflavoenzymes that play an important role in purine catabolism. These enzymes, which include xanthine dehydrogenase and xanthine oxidase, oxidize hypoxanthine to xanthine and xanthine to uric acid, respectively. In normal cells, purine metabolism can be initiated by two major pathyways. Initially, ATP, a purine for many energy-requiring enzymatic reactions, can be converted to inosine monophosphate by deaminase and form inosine after dephosphorylation. Purine can become adenosine by removal of a phosphate group and convert to inosine. Inosine is further converted to hypoxanthine and is then oxidized to xanthine. Xanthine is also synthesized from guanine, which is converted from guanine monophosphate. Through the activity of xanthine oxidoreductase, xanthine is then converted to uric acid (Fig. 2). In purine metabolism, there are many enzymes involved in the conversion to uric acid. Xanthine oxidases are particularly important, as their activity is accompanied by ROS production. These enzymes have two forms: xanthine dehydrogenase, which preferentially uses $\mathrm{NAD}^{+}$as an electron acceptor, and xanthine oxidase, which usually uses $\mathrm{O}_{2}$ as an acceptor. During hypoxanthine oxidation to xanthine in normal cells, there is simultaneous reduction of $\mathrm{NAD}^{+}$or $\mathrm{O}_{2}$, and production of NADH by xanthine dehydrogenase [17]. In an ischemic state, xanthine dehydrogenase is shifted to xanthine oxidoreductase due to a lower ATP level. In addition, xanthine dehydrogenase is shifted to xanthine oxidoreductase due to oxidation of critical cysteines and/or limited proteolysis. When blood flow is restored to ischemic tissue, xanthine oxidase reacts with $\mathrm{O}_{2}$ to induce hypoxanthine to form xanthine and uric acid, using oxygen as the final electron acceptor. During the formation of xanthine and uric acid, superoxide $\left(\mathrm{O}_{2}{ }^{-}\right)$ and hydrogen peroxide $\left(\mathrm{H}_{2} \mathrm{O}_{2}\right)$ are released, inducing more oxidative stress. ROS produced by xanthine oxidoreductase lead to cytokine cascades and pathological conditions via the expression of adhesion proteins, such as P-selectin and ICAM-1 [18].

Pharmacological inhibition of ROS production from purine metabolism has been reported in previous studies. Allopurinol and oxypurinol are commonly used to inhibit xanthine oxidase activity to decrease serum uric acid production. However, recent studies have reported inconsistent results relating to the blockade of xanthine oxidase to prevent ROS 


\section{Cellular Physiology Cell Physiol Biochem 2018:46:1650-1667 \begin{tabular}{l|l} 
DOI: 10.1159/000489241 & and Biochemistry 2018 The Author(s). Published by S. Karger AG, Basel \\
wublished online: April 25, 2018 & wwrger.com/cpb
\end{tabular}}

Wu et al.: Cellular Mechanisms of I/R Injury

formation [14, 17-21]. Several reasons have been proposed. For example, the required doses of allopurinol and oxypurinol are higher than the theoretical doses, and a pharmacological inhibitor may exert antioxidative effects [21]. In addition, studies have demonstrated that xanthine oxidase has several functions, including nitrate reductase activity, which increases production of nitric oxide $[19,20,22]$. The production of nitric oxide can minimize ischemiareperfusion injury by stimulating vasodilation and inhibiting inflammatory responses. For these reasons, only inhibiting xanthine oxidase via a pharmacological inhibitor may not result in better clinical outcomes.

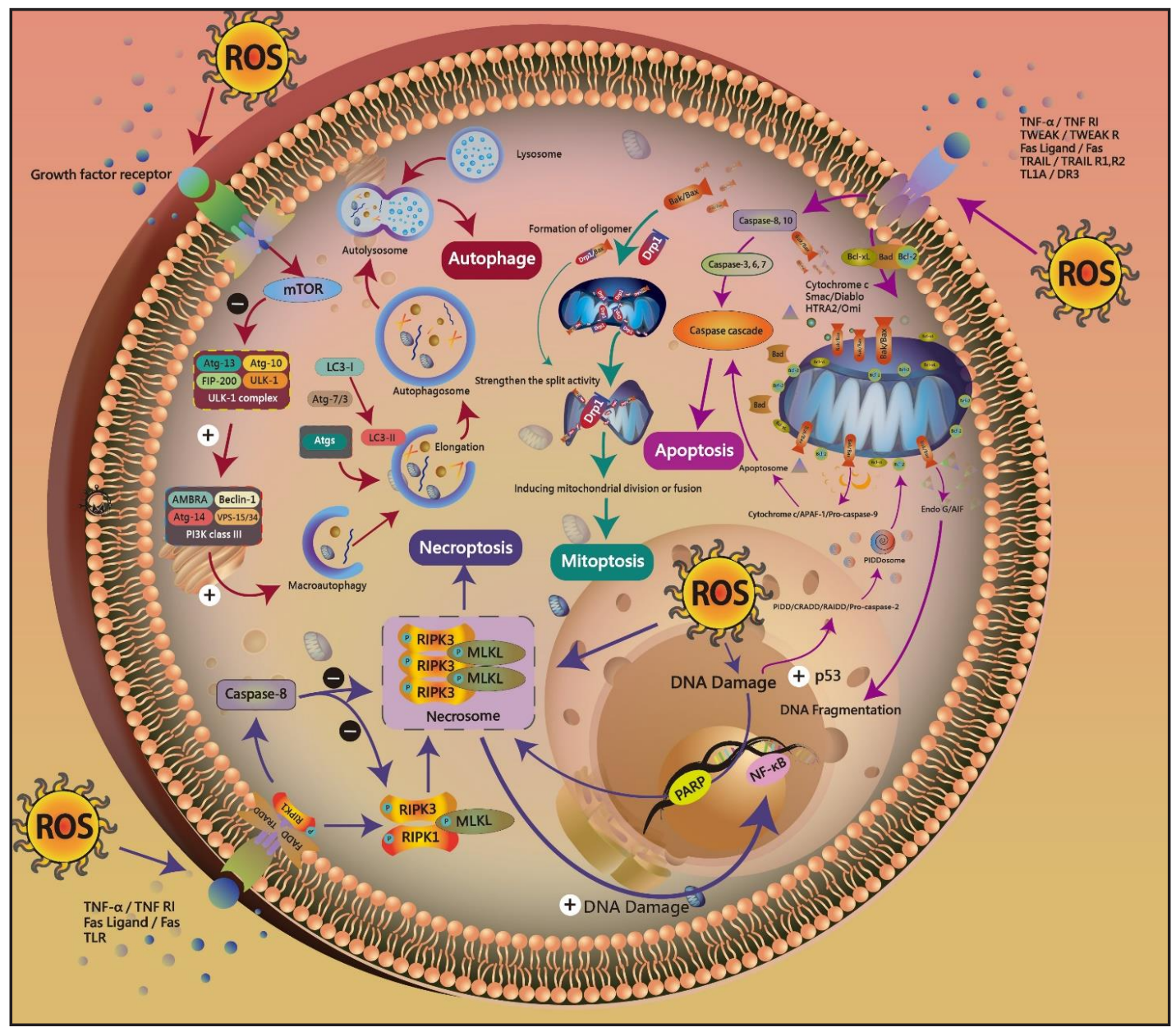

Fig. 3. Mechanism of ischemia-reperfusion injury inducing cell death. Apoptosis: Hypoxic stress from ischemia-reperfusion injury induces both the extrinsic- and intrinsic pathways. The death ligands, TNF- $\alpha$, TWEAK, Fas Ligand, TRAIL, and TL1A, activate the caspase cascade to cause cell death via proteolysis. ROS also activate the pro-apoptotic Bcl-2 family to change the integrity of the mitochondrial membrane, leading to the caspase cascade. Mitoptosis: BAX/BAK regulate Drp1, leading to mitochondrial cleavage and fusion. The formation of oligomers of BAX/Drp1 strengthens the split activity and increases mitochondrial membrane potential, cytochrome c release, and cell death. Necrosis and necroptosis: Various stimuli activate necroptosis via the necrosome. The intracellular adapter molecules FADD and TRADD activate RIPK1 and promote formation of the necrosome with RIPK1 and MLKL. ROS-induced DNA damage also promotes necrosome formation by activating PARP. The overexpression of poly-(ADP-ribose) polymerase-1 (PARP-1) leads to necrotic cell death by depletion of ATP and irreversible cellular energy failure. Autophagy: The oxidative stress in ischemia-reperfusion injury inhibits the activity of mTOR, leading to formation of the ULK-1 complex and PI3K class III, which then induce autophagy. The interaction between Atg proteins and LC-1 promotes the formation of autophagosomes. Autophagosomes fuse with lysosome to induce autophagy. 


\section{Cellular Physiology Cell Physiol Biochem 2018;46:1650-1667 \\ \begin{tabular}{l|l} 
and Biochemistry Published onlıne: April 25, 2018 & $\begin{array}{l}\text { (c) } 2018 \text { The Author(s). Published by S. Karger AG, Basel } \\
\text { www.karger.com/cpb }\end{array}$
\end{tabular} \\ Wu et al.: Cellular Mechanisms of I/R Injury}

\section{Mechanisms of NADPH oxidase induction of oxidative stress in ischemia-reperfusion injury}

The Nox/Duox family of NADPH oxidases, comprised of multiprotein complexes with Nox-1 to Nox-5 and dual oxidases (Duox)-1 and Duox-2, also produces ROS in ischemiareperfusion injury $[23,24]$. NOX enzymes generally consist of six transmembrane domains with two histidines at domains III and V, spanning two hemes [25-27]. The flavin adenine dinucleotide (FAD) and NADPH binding domains localize to the cytoplasmic $\mathrm{COOH}$ terminus of NOX enzymes [23]. NOX enzymes use oxygen as final electron acceptors via NADPH, FAD, and heme groups $[28,29]$. Recent studies have reported that NOX enzymes are involved in ROS production in ischemia-reperfusion injury by their overexpression and increased activity [30-34]. NOX enzymes immediately produce $\mathrm{O}_{2}{ }^{\circ}$, which is transferred to $\mathrm{H}_{2} \mathrm{O}_{2}$ via enzymes. The superoxide passes through the membrane via the pores of anion channels, leading to NO degradation, peroxynitrite formation, and protein tyrosine nitration. Superoxide also reduces iron centers within aconitase and alkalinizes intracellular organelles. Hydrogen peroxide passes through the membrane to oxidize cysteine, inactivate tyrosine phosphatases and the serine-threonine phosphatase calcineurin, react with peroxidases, and cause cell toxicity [24]. Hypoxia also induces hypoxia inhibitory factor-1 $\alpha$ (HIF-1 $\alpha$ ) to promote activation of NOX enzymes. Oxidative stess increases the production of HIF- $1 \alpha$ to establish a positive feedback loop. Moreover, after restoring blood flow to ischemic tissue, cells release several chemical mediators to activate NADPH oxidase, such as phospholipase A2, TNF- $\alpha$, IL$1 \beta$, IFN- $\gamma$, and angiotension II (Fig. 2). The release of phospholipase A2 induces production of platelet activating factor, leading to an increase in the tissue levels of thromboxane and leukotrienes, which promote local inflammation [35-38]. NOX-derived ROS in post-ischemic tissue may cause inflammatory cell accumulation, leading to reperfusion injury in a variety of organs, such as the heart, brain, intestine, stomach, lung, and skeletal muscle [39-45]. Cytokines produced by macrophages and mast cells promote overexpression of NADPH oxidase [46, 47]. Angiotensin II also stimulates local angiotensin II receptors to incease the expression of NADPH oxidase, resulting in ischemia-reperfusion injury via angiotensin converting enzyme [48-52].

Pharmacological inhibition of ROS production from NOX enzymes by apocynin or diphenyliodonium has been reported [53-57]. Apocynin inhibits NOX enzymes by decreasing membrane translocation of p47phox and p67phox. Diphenyliodonium is a flavoprotein inhibitor that decreases the electron transport function of NOX enzymes. In endothelial cells, inhibiton of NOX activation decreases NADPH oxidase expression and superoxide production. It also reduces the expresion of adhesion proteins, including E-selectin and ICAM [58]. Similar results were reported in cardiac cells, lung cells, and brain cells [59-61]. However, curcumin, apocynin and diphenyliodonium have antioxidant functions that inhibit nitric oxide synthesis, xanthine oxidase, cytochrome P450 reductase, and mitochondrial enzymes. For these reasons, definitively attributing the neutralization of ischemia-reperfusion injury by apocynin and diphenyliodonium to NOX enzyme inhibition is difficult [62-67].

\section{Mechanisms of NOS induction of oxidative stress in ischemia-reperfusion injury}

The three recognized types of NOS are neuronal NOS (nNOS), endothelial NOS (eNOS), and inducible NOS (iNOS) $[68,69]$. All types of NOS produce nitric oxide (NO) by the conversion of L-arginine to L-citrulline. NO also plays a protective role via its antioxidative and anti-inflammatory functions [69-72]. However, in a hypoxic state, NOS is converted to NOS uncoupling and produces ROS to induce ischemia-reperfusion injury. The structure of NOS consists of an oxygenase, which contains heme and tetrahydrobiopterin $\left(\mathrm{BH}_{4}\right)$ and binds arginine, and a reductase domain, which contains flavins (FAD and FMN) and binds NADPH. Tetrahydrobiopterin $\left(\mathrm{BH}_{4}\right)$ is a cofactor, synthesized from guanosine $5 \square$-triphosphate (GTP) via GTP cyclohydrolase I, quinonoid dihydrobiopterin $\left(\mathrm{BH}_{2}\right)$, and sepiapterin [73-77]. The 
$\mathrm{BH}_{4}$ concentration plays a critical role in NO production by regulating eNOS activity. However, in ischemia-reperfusion injury, oxidative stress oxidizes $\mathrm{BH}_{4}$, causing the tissue level of $\mathrm{BH}_{4}$ to decrease. Decreases in the $\mathrm{BH}_{4} / \mathrm{NOS}$ ratio induces the uncoupling of NOS and superoxide, resulting in cell death (Fig. 2). The mechanisms of ROS production in ischemia-reperfusion injury are multifactorial and complex. In the ischemic stage, ROS produced from the xanthine oxidase system, NADPH oxidase system, mitochondrial electron transport chain, and uncoupled NOS system may accumulate in cells and reduce the effects of an antioxidative agent. After the blood supply is restored to ischemic tissue, oxidative stress may lead to cell damage and cell death if the severity is sufficient. The mechanism of ischemia-reperfusioninjury-induced cell death is discussed in the following section.

\section{Cell damage in ischemia-reperfusion injury}

The total tissue injury induced by ischemia-reperfusion injury is divided into two parts: ischemia injury and reperfusion injury. Ischemic injury may initially cause hypoxia and hyponutrition. After prolonged ischemia, the metabolic products from cells are retained and cause metabolic acidosis. When the blood supply is re-established, local inflammation and ROS production increase, leading to secondary injury. The cell response is dependent on the severity of total tissue injury [78]. Cell damage induced by prolonged ischemia-reperfusion injury may lead to apoptosis, autophagy, necrosis, and necroptosis [79-81]. Moderate ischemia-reperfusion injury may cause cell dysfunction by autophagy and activate recovery systems for survival. If damage is severe, cell death may be induced via apoptotic or necrotic pathways [82]. A shorter duration of ischemia-reperfusion injury may activate cell survival programs to control ROS generation and cell damage [83]. Different mechanisms of cell death may be induced based on different pathogenesis pathways of ischemia-reperfusion injury. Four types of cell death mechanisms induced in ischemia-reperfusion injury are discussed in the next section.

\section{Apoptosis and mitoptosis}

Cell death is important in the pathogenesis of several diseases. Apoptosis is a process of programmed cell death that is activated under hypoxic stress in ischemic injury and during the production of ROS in reperfusion injury $[84,85]$. Apoptotic mechanisms are divided into two major pathways: the extrinsic- and intrinsic pathways. Both pathways can crosstalk and influence the other. The extrinsic pathway, also known as the death receptor pathway, is activated by death ligands and receptors, including TNF- $\alpha$, TWEAK, Fas ligand, TRAIL, and TL1A. This death-signaling complex activates a protease, caspase-8, to cleave caspase-3, which then induces cell death via proteolysis in damaged cells. The intrinsic pathway, also known as the mitochondrial pathway, is activated by hypoxia, radiation, or cellular toxins, and changes the integrity of the mitochondrial membrane, leading to activation of the pro-apoptotic Bcl-2 family. In ischemia-reperfusion injury, cytoplasmic Bad increases and binds to Bcl-2 and Bcl-XL. In parallel, Bax and Bak are processed and inserted into the mitochondrial membrane to release downstream pro-apoptotic proteins such as cytochrome c, Smac/Diablo, HTRA2/Omi, apoptosis-inducing factor, and endonuclease G. Cytochrome c binds apoptotic protease activating factor 1 (APAF-1) to activate pro-caspase- 9 to form the apoptosome. The apoptosome induces a caspase cascade to promote apoptosis via activation of caspase-9 [86]. Endo G also interacts with AIF to cause DNA fragmentation. After ROSinduced DNA damage, p53 induces the formation of the PIDDosome by the expression of PIDD and interaction of CRADD/RAIDD and pro-caspase-2. The complex activates caspase- 2 and cleaves downstream caspases to drive apoptosis (Fig. 3). Ischemia-reperfusion injuryinduced apoptosis is not as common as necrosis [87]. However, apoptosis is not as frequently accompanied by a local inflammatory response. 
Mitochondria become fragmented to achieve programmed cell death in a process termed mitoptosis [88]. However, during mitoptosis, BAX and BAK regulate mitochondrial cleavage and can be linked to the mitochondrial outer membrane in conjunction with Drp1 rather than through the regulation of other cleavage proteins such as Fis1 (fission 1) and Mdv1 (mitochondrial division 1). Regulation of mitochondrial cleavage and fusion of any protein cause inactivation of the protein, and leads to intracellular mitochondrial division or fusion abnormalities [89]. The K38A Drp1 (dynamin-related protein 1) pathway inhibits Drp1 function, leading to mitosis, is inhibited, and fusion is not affected, mitochondrial morphology showed long strip, than the normal cell mitochondrial length increased significantly in cardiac ischemia-reperfusion injury [90]. Excessive expression of Drp1 resulted in overexpression of mitochondria, a significant decrease in the number of mitochondria, increased mitochondrial membrane potential, cytochrome c release, and cell death [91]. Which BAX/Drp1 cannot only co-split, damage to the heavier cells will also occur BAX/Drp1 formation of oligomer to strengthen the split activity [92]. BAX is a pro-apoptotic protein that assists mitochondrial division. In addition, BAX can change the distribution of mitochondria to promote mitochondrial fusion through the activation of mitochondrial fusion protein Mfn2 (mitofusion 2) synthesis (Fig. 3). Cristae in the mitochondrial inner membrane structure also play a key role in the regulation of cytochrome $\mathrm{c}$ during apoptosis. An important protein molecule in cristae is OPA1 (optic atrophy 1). Abnormal OPA1 function may cause damage to the endometrial structure, promoting mitochondrial fragmentation and apoptosis [93]. The regulatory mechanism is through Bid to distract cristae wrinkles to destroy the OPA1 formation of oligomer to facilitate the connection and maintain the form of cristae. In addition, the release of cytochrome c promotes the release of additional cytochrome c. In contrast, overexpression of OPA1 delays structural changes in the mitochondrial inner membrane and reduces the damage caused by Bid in heart ischemia injury [94].

\section{Necrosis and necroptosis}

Necrosis, like apoptosis, is considered a form of the execution phase of programmed cell death, although the consequences of necrotic and apoptotic cell death are quite different for a whole organism. Necrosis is a form of cell death characterized by early plasma membrane permeation and organelle swelling. Necrosis occurs when cells are subjected to excessive external stress [95]. Necrosis is considered passive and unregulated. Although necrosis is widely found in human pathology, there have been few studies on the mechanism of necrosis regulation in ischemia-reperfusion injury [96]. Necrosis is caused by a dramatic change in the external environment caused by physical, chemical, or biological damage. Cell disintegration, organ swelling and loss of mitochondrial function are the main features of necrosis, and the process induces a large number of local inflammatory responses in ischemic tissue [97]. Although necrosis is observed in a variety of pathophysiological processes, traditional necrosis is considered unregulated. However, recent studies have confirmed the characteristics of necrosis, known as necroptosis in mouse models of inflammation and ischemia-reperfusion injury [98]. Necroptosis is a form of programmed cell death that is controlled by death signals and displays a death pattern like that of necrosis [98]. Local ischemia is caused by obstruction of blood flow to tissue, resulting in a limited supply of oxygen and nutrients, which if prolonged, can impair energy metabolism and cell death [99]. The recovery of blood loss (reperfusion) leads to the reintroduction of oxygen and the production of ROS, leading to cell death associated with inactivation $[100,101]$.

The formation of a necrosome key protein in the RIP1, RIP3 is phosphorylation, not only the structural changes, because the two protein active domains have high degree of similarity. Promoting TNFR complex II more stable, and at the same time activation of RIP3 downstream regulatory signal path. RIP1 interacts with RIP3 and forms necrosome-induced necroptosis with dimerization, while cell death is still performed with conventional apoptosis or necrosis in the absence of ischemia-reperfusion injury in rat retina [96]. However, in the 
case of RIP3 overexpression, not only was a high concentration of ROS detected, but also enhanced NF- $\kappa B$ protein regulation, this regulation ability was significantly lower than that of RIP1, so many diseases are in this way necroptosis way to control. These findings suggest that RIP3 may be associated with the activity of RIP3 in disease formation and that RIP3 can control the transformation of cells in vivo to necroptosis [102]. In addition to relying on the activity of RIP1 and RIP3, necroptosis, including RIP1 activity, can be directly or indirectly involved in the phosphorylation of RIP3 at Ser161 phosphate sites. Studies have shown that viral infection in mouse cells is mainly regulated by RIP3 rather than RIP1regulated necroptosis [103]. However, increasing evidence has clarified that certain types of necrosis are mediated by the intrinsic cellular procedures that are strictly controlled and are now called necroptosis (Fig. 3) [95]. Because of the association between necroptosis and inflammation in the pathogenesis of human diseases, understanding the molecular mechanisms underlying necrosis and the pathophysiological importance of necroptosis remains an important goal of ischemia-reperfusion injury research.

\section{Autophagy}

Autophagy is a biological process in which biological macromolecules and damaged organelles in the cytoplasm are degraded in membrane vesicles. Autophagic common inclusions mainly contain cytoplasmic components and some damaged organelles such as granules. According to the source of the autophagosomes, the inclusion is transported to the lysosome in different ways, and the autophagy process is roughly divided into three main types: 1. macroautophagy: the main source of the membrane originates from the endoplasmic reticulum and Golgi apparatus. The monolayer film of the net forms a doublelayer separation film with a cup-like structure, and completely contains the object to be degraded to form an autophagosome, which is then fused with the lysosomal membrane to form an autophagosome. The degradation products are degraded by lysosomal enzymes. 2 . microautophagy: the lysosomal membrane is directly wrapped to be degraded and digested in the lysosome. 3. chaperone-mediated autophagy (CMA): the chaperone is first bound to the protein to be degraded to guide the transport of the substance to lysosomes, digested and decomposed by enzymatic action, and the CMA pathway is a soluble protein molecule. Therefore, the CMA pathway has a clear selectivity, at this point with the first two ways there is a huge difference [104].

During ischemia-reperfusion injury, cells induce cell autophagy [105]. Autophagy is regulated by autophagy-related proteins, which are encoded by autophagy-related genes (ATG). Autophagy is mainly mediated by hormones. The ULK1-Atg13-RB1CC1-Atg10 complex formed by Atg13 and RB1CC1/Atg17 interacts with mTORC1 and participates in the initial phase of autophagy. In the absence of nutrients and energy, cells display inhibited mTOR activity, while ULK1 is activated, and then control Atg13 and RB1CC, autophagy membrane began to form [106]. Autophagic vesicle extension requires the participation of the Atg12-Atg5-Atg16 complex and Atg8/LC3, two ubiquitination binding systems. The initial free LC3-I in the cytoplasm binds to PE and is lipidated to form LC3-II, which is localized to the phagocytic membrane. The presence of specific markers of LC3-II, the formation of autophagosomes, can be used as autophagy-induced subject matter, autophagosomes in the lysosomal hydrolase was degraded [107]. Regulatory autophagy pathways include mTOR, PI3K-Akt, p53, CA-AMPK and endoplasmic reticulum pressure (Fig. 3) [108, 109]. mTOR is located downstream of PI3K-Akt signaling, regulates cell growth, and inhibits the initial process of autophagy $[110,111]$. The mTOR inhibitor rapamycin can induce autophagy. At the beginning of reperfusion, mitochondria generate ATP, which induces autophagy. In parallel, reperfusion can induce calcium and accumulation in mitochondria. When increased autophagy did not completely neutralize the reperfusion pressure, liver cell damage occurred [112]. In previous studies, the use of chloroquine and GFP-LC3 to observe the autophagic image confirmed that the initial stage of reperfusion promotes autophagy. However, 
autophagy did not clear all dysfunctional mitochondria during the intracellular perfusion stage, as there was mitochondrial calcium overload and excessive ROS, which exceeded the autophagic clearance ability, leading to mitochondrial permeability transition (MPT) [112]. MPT leads to irreversible oxidative phosphorylation de-coupling, ATP formation is insufficient, and there is energy failure, eventually leading to hepatocellular death [113]. An understanding of the mechanisms that regulate autophagy to reduce the ischemiareperfusion injury has a guiding significance.

\section{Therapeutic approaches in ischemia-reperfusion injury}

The clinical manifestations of ischemia-reperfusion injury have been previously described, and include myocardial hibernation, acute heart failure, cerebral dysfunction, gastrointestinal dysfunction, systemic inflammatory response syndrome, and multiple organ dysfunction syndrome. Therapeutic approaches are different according to the injured organ. For sepsis, timely resuscitation with adequate fluids and vasopressors is recommended [1-7]. In acute myocardial infarction, reperfusion arrhythmias are common complications in patients undergoing revascularization. To control malignant arrhythmias, staged gradual reflow or transient acid reperfusion are useful management approaches to reduce ischemia-reperfusion injury $[114,115]$. In acute ischemic extremity injuries, the first step is shortening ischemic time, correcting metabolic acidosis, and preventing acute renal injury using metabolic techniques or anti-inflammatory treatments [116-118]. In this review, we focus on the therapeutic approaches of cell biology in ischemia-reperfusion injury.

\section{Nitric oxide corresponding protection strategy}

NO is synthesized by vascular endothelial cells to prevent the reduction of antioxidants in the body to reduce oxidative stress injury. In ischemia and reperfusion injury, NO reduces the harmful effects of endothelin and improves microcirculation. Using ischemia-reperfusion injury animal experiments, Peralta et al. [119] found that NO significantly improved liver function by improving liver blood flow. Adenosine plays a critical role in stimulating the production of NO in ischemia-reperfusion injury. In a study by Lang et al. [120], using NO inhalants after liver transplantation protected hepatocytes, promoted liver function recovery, and shortened the duration of hospital stay. In a meta-analysis by Bice et al. [121], NO interventions also limited infarct size during the early reperfusion period. In myocardial injury, inhaled gaseous NO inhibited cardiomyocyte apoptosis and reduced infarct size [122125]. The concentration of creatine kinase also decreased [122-124, 126, 127]. Increasing NO mediated respiratory complexes, leading to improved myocardial oxygen consumption and reduced production of superoxide. Administration of NO for ischemia-reperfusion injury may be useful to control ROS formation and cell death.

\section{Nuclear transcription factors}

$\mathrm{NF}-\kappa \mathrm{B}$ is a dimer redox-sensitive transcription factor consisting of p50 and p65 with an important role in ischemia-reperfusion injury involving a rapid response to oxidative stress. The activation of NF-kB regulates cell survival, apoptosis and inflammation, via effectors such as MnSOD, Bcl-2, TNF- $\alpha$, ICAM and P-selectin. In normal Kupffer cells, NF- $\kappa B$ is inactive, and its complexes inhibit protein I-кB formation. In ischemia-reperfusion injury, NF-кB is activated in a variety of ways: the classical pathway of NF- $\mathrm{KB}$ activation, in which IкB is phosphorylated by its kinase complex, followed by degradation; without the IKK complex (ІкB kinase) pathway, ІкB $\alpha$ tyrosine residues are phosphorylated and NF-кB is activated. Activated NF- $\mathrm{KB}$ is transferred to the nucleus and activates the target gene for transcription, 
thereby participating in ischemia-reperfusion injury. NF- $\mathrm{B} \mathrm{exerts} \mathrm{its} \mathrm{effects} \mathrm{by} \mathrm{regulating}$ NOS, cytokines (TNF- $\alpha$, IL-1), chemokines (ENA78), and ICAM-1. Matsui et al. [128] found that activation of NF-кB was associated with ischemia-reperfusion injury in animal experiments, and administration of NF-кB inhibitors reduced ischemia-reperfusion injury.

\section{Reduced ischemia-reperfusion injury caused by apoptosis}

Cells release ATP through calcium as a distress signal to attract phagocytic cells and inhibiting renal ischemia-reperfusion injury cell by apoptosis is a treatment strategy for ischemia-reperfusion injury. Studies have shown that damaged proximal tubular cells produce matricellular thrombospondin 1 (THBS1) and High Mobility Group Box 1 (HMGB1), which can induce apoptosis; administration of THBS1 and HMGB1 inhibitors protected mice from kidney ischemia-reperfusion injury [129-131]. Previous studies have also suggested that an increase in platelet-derived factors can lead to an increase in GSK-3ßSer9 phosphorylation levels and that Ser9 phosphorylation can inhibit apoptosis. Hotchkis et al. [132] found that the immunosuppressive agent cyclosporine inhibited the mitochondrial permeability of renal tubular cells through MPTP open inhibitor, is an important inhibitor of tubular death in the preparation [133].

\section{Calcium overload and corresponding protection measures}

In the process of ischemia-reperfusion injury, ischemia and hypoxia disturb the physiological balance of cells, causing an insufficient cell energy supply. A lower ATP level decreases the activity of energy-dependent $\mathrm{Na}^{+}-\mathrm{K}^{+}$-ATPase, leading to an increase in intracellular $\mathrm{Na}^{+} . \mathrm{Na}^{+}-\mathrm{Ca}^{+2}$ ion exchange compensates to reduce the concentration of intracellular $\mathrm{Na}^{+}$. To maintain the membrane potential, the compensation of ion exchange results in a higher concentration of intracellular $\mathrm{Ca}^{+2} ; \mathrm{Ca}^{+2}-\mathrm{ATP} / \mathrm{Ca}^{+2}-\mathrm{Mg}^{+2}-\mathrm{ATPase}$ dysfunction worsens this condition. Calcium overload injures cells from multiple aspects, by increasing ROS, activating inflammatory cells, inducing cell apoptosis, destroying cell membranes, and interfering with mitochondrial function. Pretreatment with verapamil, a voltage-dependent calcium channel blocker, prior to animal ischemia-reperfusion resulted in significant inhibition of $\mathrm{Ca}^{+2}$ accumulation in hepatocytes [134]. Mitochondrial ATD-sensitive potassium channels (mitoKATP) and mPTP differences altered mitochondrial $\mathrm{Ca}^{+2}$ balance, induced mitoKATP opening to mitochondrial membrane partial depolarization and inhibition of mPTP can reduce $\mathrm{Ca}^{+2}$ influx, thereby reducing calcium overload [135]. $\mathrm{A} \mathrm{Na}^{+}-\mathrm{Ca}^{+2}$ exchange inhibitor, KB-R7943, inhibited apoptosis, activated $\mathrm{K}^{+}$-ATP channels, promoted $\mathrm{K}^{+}$and $\mathrm{Ca}^{+2}$ exchange, and inhibited calcium overload [136].

\section{Conclusion}

The clinical manifestations of ischemia-reperfusion injury are diverse. Ischemiareperfusion injury is a critical challenge for physicians from a treatment standpoint. In this review, we presented current research findings on the basic pathophysiology of ischemiareperfusion injury, especially the involvement of ROS and cell death pathways. Several principles described here are worth reiterating. First, hypoxia and ischemia induce anaerobic metabolism and dysfunction of the electron transport chain in mitochondria. Decreased ATP production causes dysfunction of ion-exchange channels, leading to retention of sodium, hydrogen and calcium, which results in cell swelling and impaired enzyme activity in the cytoplasm. Second, mitochondrial damage and electrolyte imbalance in the reperfusion state promotes the production of oxidative stress via the NADPH oxidase system, NOS system, and xanthine oxidase system. Finally, ROS retention induces cell damage and leads to cell death 


\section{Cellular Physiology Cell Physiol Biochem 2018;46:1650-1667 \begin{tabular}{l|l} 
DOI: 10.1159/000489241 & $\begin{array}{l}\text { O 2018 The Author(s). Published by S. Karger AG, Basel } \\
\text { wwww.karger.com/cpb }\end{array}$
\end{tabular} \\ Wu et al.: Cellular Mechanisms of I/R Injury}

via autophagy, mitoptosis, necrosis and necroptosis, and apoptosis. Although the detailed mechanisms associated with ischemia-reperfusion injury remain to be fully elucidated, we believe an understanding of the pathophysiology has the potential to provide a strong foundation for the exploration of new therapeutic avenues.

\section{Acknowledgements}

This study was funded by grants RD106083 and RD106084 from Show Chwan Memorial Hospital, Taiwan.

\section{Disclosure Statement}

No conflict of interests exists.

\section{References}

1 Briegel J, Mohnle P: [International guidelines of the Surviving Sepsis Campaign : update 2012]. Anaesthesist 2013;62:304-309.

-2 Dellinger RP, Levy MM, Rhodes A, Annane D, Gerlach H, Opal SM, Sevransky JE, Sprung CL, Douglas IS, Jaeschke R, Osborn TM, Nunnally ME, Townsend SR, Reinhart K, Kleinpell RM, Angus DC, Deutschman CS, Machado FR, Rubenfeld GD, Webb S, Beale RJ, Vincent JL, Moreno R: Surviving Sepsis Campaign: international guidelines for management of severe sepsis and septic shock, 2012. Intensive Care Med 2013;39:165-228.

3 Grek A, Booth S, Festic E, Maniaci M, Shirazi E, Thompson K, Starbuck A, McRee C, Naessens JM, Moreno Franco P: Sepsis and Shock Response Team: Impact of a Multidisciplinary Approach to Implementing Surviving Sepsis Campaign Guidelines and Surviving the Process. Am J Med Qual 2017;32:500-507.

-4 Jones AE, Puskarich MA: The Surviving Sepsis Campaign guidelines 2012: update for emergency physicians. Ann Emerg Med 2014;63:35-47.

5 Rhodes A, Evans LE, Alhazzani W, Levy MM, Antonelli M, Ferrer R, Kumar A, Sevransky JE, Sprung CL, Nunnally ME, Rochwerg B, Rubenfeld GD, Angus DC, Annane D, Beale RJ, Bellinghan GJ, Bernard GR, Chiche JD, Coopersmith C, De Backer DP, French CJ, Fujishima S, Gerlach H, Hidalgo JL, Hollenberg SM, Jones AE, Karnad DR, Kleinpell RM, Koh Y, Lisboa TC, Machado FR, Marini JJ, Marshall JC, Mazuski JE, McIntyre LA, McLean AS, Mehta S, Moreno RP, Myburgh J, Navalesi P, Nishida O, Osborn TM, Perner A, Plunkett CM, Ranieri M, Schorr CA, Seckel MA, Seymour CW, Shieh L, Shukri KA, Simpson SQ, Singer M, Thompson BT, Townsend SR, Van der Poll T, Vincent JL, Wiersinga WJ, Zimmerman JL, Dellinger RP: Surviving Sepsis Campaign: International Guidelines for Management of Sepsis and Septic Shock: 2016. Intensive Care Med 2017;43:304-377.

6 Shrestha GS, Kwizera A, Lundeg G, Baelani JI, Azevedo LCP, Pattnaik R, Haniffa R, Gavrilovic S, Mai NTH, Kissoon N, Lodha R, Misango D, Neto AS, Schultz MJ, Dondorp AM, Thevanayagam J, Dunser MW, Alam A, Mukhtar AM, Hashmi M, Ranjit S, Otu A, Gomersall C, Amito J, Vaeza NN, Nakibuuka J, Mujyarugamba P, Estenssoro E, Ospina-Tascon GA, Mohanty S, Mer M: International Surviving Sepsis Campaign guidelines 2016: the perspective from low-income and middle-income countries. Lancet Infect Dis 2017;17:893-895.

-7 Silvestri L, van Saene HK, Rommes JH, Petros AJ, de la Cal MA, Bion JF: Surviving Sepsis Campaign guidelines 2016: omission of selective decontamination of the digestive tract deprives patients of a level 2B therapy. Minerva Anestesiol 2017

-8 Zuo Y, Wang Y, Hu H, Cui W: Atorvastatin Protects Myocardium Against Ischemia-Reperfusion Injury Through Inhibiting miR-199a-5p. Cell Physiol Biochem 2016;39:1021-1030.

-9 Levine GN, Bates ER, Blankenship JC, Bailey SR, Bittl JA, Cercek B, Chambers CE, Ellis SG, Guyton RA, Hollenberg SM, Khot UN, Lange RA, Mauri L, Mehran R, Moussa ID, Mukherjee D, Nallamothu BK, Ting HH: 2011 ACCF/AHA/SCAI Guideline for Percutaneous Coronary Intervention. A Report of the American College of Cardiology Foundation/American Heart Association Task Force on Practice Guidelines Soc Cardiovasc Angiography Interv 2011;58:e44-e122. 


\section{Cellular Physiology Cell Physiol Biochem 2018;46:1650-1667

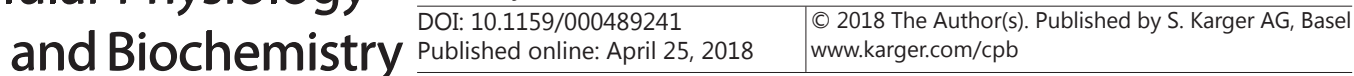 \\ Wu et al.: Cellular Mechanisms of I/R Injury}

10 Wu MY, Li CJ, Hou MF, Chu PY: New Insights into the Role of Inflammation in the Pathogenesis of Atherosclerosis. Int J Mol Sci 2017;18

11 Wang HB, Yang J, Ding JW, Chen LH, Li S, Liu XW, Yang CJ, Fan ZX: RNAi-Mediated Down-Regulation of CD47 Protects against Ischemia/Reperfusion-Induced Myocardial Damage via Activation of eNOS in a Rat Model. Cell Physiol Biochem 2016;40:1163-1174.

12 Ornellas FM, Ornellas DS, Martini SV, Castiglione RC, Ventura GM, Rocco PR, Gutfilen B, de Souza SA, Takiya CM, Morales MM: Bone Marrow-Derived Mononuclear Cell Therapy Accelerates Renal IschemiaReperfusion Injury Recovery by Modulating Inflammatory, Antioxidant and Apoptotic Related Molecules. Cell Physiol Biochem 2017;41:1736-1752.

13 Granger DN, Kvietys PR: Reperfusion injury and reactive oxygen species: The evolution of a concept. Redox Biol 2015;6:524-551.

14 De Pascali F, Hemann C, Samons K, Chen CA, Zweier JL: Hypoxia and reoxygenation induce endothelial nitric oxide synthase uncoupling in endothelial cells through tetrahydrobiopterin depletion and S-glutathionylation. Biochemistry 2014;53:3679-3688.

15 Moens AL, Champion HC, Claeys MJ, Tavazzi B, Kaminski PM, Wolin MS, Borgonjon DJ, Van Nassauw L, Haile A, Zviman M, Bedja D, Wuyts FL, Elsaesser RS, Cos P, Gabrielson KL, Lazzarino G, Paolocci N, Timmermans J-P, Vrints CJ, Kass DA: High-Dose Folic Acid Pretreatment Blunts Cardiac Dysfunction During Ischemia Coupled to Maintenance of High-Energy Phosphates and Reduces Postreperfusion Injury. Circulation 2008;117:1810-1819.

16 Perkins K-AA, Pershad S, Chen Q McGraw S, Adams JS, Zambrano C, Krass S, Emrich J, Bell B, Iyamu M, Prince C, Kay H, Teng JC-w, Young LH: The effects of modulating eNOS activity and coupling in ischemia/ reperfusion (I/R). Naunyn Schmiedebergs Arch Pharmacol 2012;385:27-38.

17 Chung HY, Baek BS, Song SH, Kim MS, Huh JI, Shim KH, Kim KW, Lee KH: Xanthine dehydrogenase/xanthine oxidase and oxidative stress. Age (Omaha) 1997;20:127-140.

18 Lee M-C-i, Velayutham M, Komatsu T, Hille R, Zweier JL: Measurement and Characterization of Superoxide Generation from Xanthine Dehydrogenase: A Redox-Regulated Pathway of Radical Generation in Ischemic Tissues. Biochemistry 2014;53:6615-6623.

19 Berry CE, Hare JM: Xanthine oxidoreductase and cardiovascular disease: molecular mechanisms and pathophysiological implications. J Physiol 2004;555:589-606.

20 Cantu-Medellin N, Kelley EE: Xanthine oxidoreductase-catalyzed reactive species generation: A process in critical need of reevaluation. Redox Biol 2013;1:353-358.

21 Das DK, Engelman RM, Clement R, Otani H, Prasad MR, Rao PS: Role of xanthine oxidase inhibitor as free radical scavenger: A novel mechanism of action of allopurinol and oxypurinol in myocardial salvage. Biochem Biophys Res Commun 1987;148:314-319.

22 Harrison R: Structure and function of xanthine oxidoreductase: where are we now? Free Radic Biol Med 2002;33:774-797.

23 Bedard K, Krause K-H: The NOX Family of ROS-Generating NADPH Oxidases: Physiology and Pathophysiology. Physiol Rev 2007;87:245-313.

24 Bedard K, Krause KH: The NOX family of ROS-generating NADPH oxidases: physiology and pathophysiology. Physiol Rev 2007;87:245-313.

-25 Brandes RP, Weissmann N, Schröder K: Nox family NADPH oxidases: Molecular mechanisms of activation. Free Radic Biol Med 2014;76:208-226.

26 Lassègue B, Griendling KK: NADPH Oxidases: Functions and Pathologies in the Vasculature. Arterioscler Thromb Vasc Biol 2010;30:653-661.

27 Meitzler JL, Antony S, Wu Y, Juhasz A, Liu H, Jiang G, Lu J, Roy K, Doroshow JH: NADPH Oxidases: A Perspective on Reactive Oxygen Species Production in Tumor Biology. Antioxid Redox Signal 2014;20:2873-2889.

28 Paravicini TM, Touyz RM: NADPH oxidases, reactive oxygen species, and hypertension: clinical implications and therapeutic possibilities. Diabetes Care 2008;31:S170-180.

29 Sedeek M, Nasrallah R, Touyz RM, Hébert RL: NADPH Oxidases, Reactive Oxygen Species, and the Kidney: Friend and Foe. J Am Soc Nephrol 2013;24:1512-1518.

-30 Ma MW, Wang J, Zhang Q Wang R, Dhandapani KM, Vadlamudi RK, Brann DW: NADPH oxidase in brain injury and neurodegenerative disorders. Mol Neurodegener 2017;12. 


\section{Cellular Physiology Cell Physiol Biochem 2018;46:1650-1667 \begin{tabular}{l|l} 
DOI: 10.1159/000489241 & $\begin{array}{l}\text { O 2018 The Author(s). Published by S. Karger AG, Basel } \\
\text { www.karger.com/cpb }\end{array}$ \\
\hline
\end{tabular} \\ Wu et al.: Cellular Mechanisms of I/R Injury}

-31 Miller AA, Dusting GJ, Roulston CL, Sobey CG: NADPH-oxidase activity is elevated in penumbral and nonischemic cerebral arteries following stroke. Brain Res 2006;1111:111-116.

-32 Nakagiri A, Sunamoto M, Murakami M: NADPH oxidase is involved in ischaemia/reperfusioninduced damage in rat gastric mucosa via ROS production - Role of NADPH oxidase in rat stomachs. Inflammopharmacology 2007;15:278-281.

-33 Simone S, Rascio F, Castellano G, Divella C, Chieti A, Ditonno P, Battaglia M, Crovace A, Staffieri F, Oortwijn B, Stallone G, Gesualdo L, Pertosa G, Grandaliano G: Complement-dependent NADPH oxidase enzyme activation in renal ischemia/reperfusion injury. Free Radic Biol Med 2014;74:263-273.

-34 Yokota H, Narayanan SP, Zhang W, Liu H, Rojas M, Xu Z, Lemtalsi T, Nagaoka T, Yoshida A, Brooks SE, Caldwell RW, Caldwell RB: Neuroprotection from retinal ischemia/reperfusion injury by NOX2 NADPH oxidase deletion. Invest Ophthalmol Vis Sci 2011;52:8123-8131.

-35 Dewald B, Baggiolini M: Activation of NADPH oxidase in human neutrophils. Synergism between fMLP and the neutrophil products PAF and LTB4. Biochem Biophys Res Commun 1985;128:297-304.

-36 Carden DL, Granger DN: Pathophysiology of ischaemia-reperfusion injury. J Pathol 2000;190:255-266.

-37 Granger DN, Korthuis RJ: Physiologic mechanisms of postischemic tissue injury. Annu Rev Physiol 1995;57:311-332.

-38 Fraser PA: The role of free radical generation in increasing cerebrovascular permeability. Free Radic Biol Med 2011;51:967-977.

-39 Kuzuya T, Hoshida S, Nishida M, Kim Y, Fuji H, Kitabatake A, Kamada T, Tada M: Role of free radicals and neutrophils in canine myocardial reperfusion injury: myocardial salvage by a novel free radical scavenger, 2-octadecylascorbic acid. Cardiovasc Res 1989;23:323-330.

40 Linas SL, Whittenburg D, Parsons PE, Repine JE: Mild renal ischemia activates primed neutrophils to cause acute renal failure. Kidney Int 1992;42:610-616.

-41 Linas SL, Whittenburg D, Parsons PE, Repine JE: Ischemia increases neutrophil retention and worsens acute renal failure: Role of oxygen metabolites and ICAM 1. Kidney Int 1995;48:1584-1591.

42 Mousa SA, Brown R, Thoolen MJ, Smith RD: Evaluation of the effect of azapropazone on neutrophil migration in regional myocardial ischaemia/reperfusion injury in rabbits. Br J Pharmacol 1990;100:379382.

43 Mullane KM, Read N, Salmon JA, Moncada S: Role of leukocytes in acute myocardial infarction in anesthetized dogs: relationship to myocardial salvage by anti-inflammatory drugs. J Pharmacol Exp Ther 1984;228:510-522.

44 Romson JL, Hook BG, Kunkel SL, Abrams GD, Schork MA, Lucchesi BR: Reduction of the extent of ischemic myocardial injury by neutrophil depletion in the dog. Circulation 1983;67:1016-1023.

45 Yoshida N, Yoshikawa T, Nakamura Y, Arai M, Matsuyama K, Iinuma S, Yagi N, Naito Y, Miyasaka M, Kondo M: Role of neutrophil-mediated inflammation in aspirin-induced gastric mucosal injury. Dig Dis Sci 1995;40:2300-2304.

46 Barth BM, Stewart-Smeets S, Kuhn TB: Proinflammatory Cytokines Provoke Oxidative Damage to Actin in Neuronal Cells Mediated by Rac1 and NADPH oxidase. Mol Cell Neurosci 2009;41:274-285.

-47 Park HS, Chun JN, Jung HY, Choi C, Bae YS: Role of NADPH oxidase 4 in lipopolysaccharide-induced proinflammatory responses by human aortic endothelial cells. Cardiovasc Res 2006;72:447-455.

48 Granger D, R Kvietys P: Reperfusion injury and reactive oxygen species: The evolution of a concept. Redox Biol 2015;6:523-551.

49 Kusaka I, Kusaka G, Zhou C, Ishikawa M, Nanda A, Granger DN, Zhang JH, Tang J: Role of AT1 receptors and NAD(P)H oxidase in diabetes-aggravated ischemic brain injury. Am J Physiol Heart Circ Physiol 2004;286:H2442-2451.

50 Nakagiri A, Sunamoto M, Takeuchi K, Murakami M: Evidence for the involvement of NADPH oxidase in ischemia/reperfusion-induced gastric damage via angiotensin II. J Physiol Pharmacol 2010;61:171-179.

51 Oudot A, Vergely C, Ecarnot-Laubriet A, Rochette L: Angiotensin II activates NADPH oxidase in isolated rat hearts subjected to ischaemia-reperfusion. Eur J Pharmacol 2003;462:145-154.

52 Wu B, Lin R, Dai R, Chen C, Wu H, Hong M: Valsartan attenuates oxidative stress and NF- $\kappa$ B activation and reduces myocardial apoptosis after ischemia and reperfusion. Eur J Pharmacol 2013;705:140-147.

53 Braunersreuther V, Montecucco F, Asrih M, Pelli G, Galan K, Frias M, Burger F, Quindere AL, Montessuit C, Krause KH, Mach F, Jaquet V: Role of NADPH oxidase isoforms NOX1, NOX2 and NOX4 in myocardial ischemia/reperfusion injury. J Mol Cell Cardiol 2013;64:99-107. 


\section{Cellular Physiology Cell Physiol Biochem 2018;46:1650-1667 \begin{tabular}{ll|l} 
and Biochemistry Published onlIne: Aprll 25, 2018 & $\begin{array}{l}\text { C } 2018 \text { The Author(s). Published by S. Karger AG, Basel } \\
\text { www.karger.com/cpb }\end{array}$ \\
\hline
\end{tabular} \\ Wu et al.: Cellular Mechanisms of I/R Injury}

54 Donoso P, Finkelstein JP, Montecinos L, Said M, Sánchez G, Vittone L, Bull R: Stimulation of NOX2 in isolated hearts reversibly sensitizes RyR2 channels to activation by cytoplasmic calcium. J Mol Cell Cardiol 2014;68:38-46.

-55 Kleinschnitz C, Grund H, Wingler K, Armitage ME, Jones E, Mittal M, Barit D, Schwarz T, Geis C, Kraft P, Barthel K, Schuhmann MK, Herrmann AM, Meuth SG, Stoll G, Meurer S, Schrewe A, Becker L, Gailus-Durner V, Fuchs H, Klopstock T, de Angelis MH, Jandeleit-Dahm K, Shah AM, Weissmann N, Schmidt HHHW: PostStroke Inhibition of Induced NADPH Oxidase Type 4 Prevents Oxidative Stress and Neurodegeneration. PLOS Biol 2010;8:e1000479.

-56 McCann SK, Dusting GJ, Roulston CL: Early increase of Nox4 NADPH oxidase and superoxide generation following endothelin-1-induced stroke in conscious rats. J Neurosci Res 2008;86:2524-2534.

-57 Vallet P, Charnay Y, Steger K, Ogier-Denis E, Kovari E, Herrmann F, Michel JP, Szanto I: Neuronal expression of the NADPH oxidase NOX4, and its regulation in mouse experimental brain ischemia. Neuroscience 2005;132:233-238.

58 Paysant JR, Rupin A, Verbeuren TJ: Effect of NADPH Oxidase Inhibition on E-Selectin Expression Induced by Concomitant Anoxia/Reoxygenation and TNF- $\alpha$. Endothelium 2002;9:263-271.

59 Abramov AY, Scorziello A, Duchen MR: Three distinct mechanisms generate oxygen free radicals in neurons and contribute to cell death during anoxia and reoxygenation. J Neurosci 2007;27:1129-1138.

60 Borchi E, Parri M, Papucci L, Becatti M, Nassi N, Nassi P, Nediani C: Role of NADPH oxidase in H9c2 cardiac muscle cells exposed to simulated ischaemia-reperfusion. J Cell Mol Med 2009;13:2724-2735.

61 Zhan G, Serrano F, Fenik P, Hsu R, Kong L, Pratico D, Klann E, Veasey SC: NADPH Oxidase Mediates Hypersomnolence and Brain Oxidative Injury in a Murine Model of Sleep Apnea. Am J Respir Crit Care Med 2005;172:921-929.

62 Brandes RP, Weissmann N, Schröder K: Nox Family NADPH Oxidases in Mechano-Transduction: Mechanisms and Consequences. Antioxid Redox Signal 2014;20:887-898.

63 Gianni D, Taulet N, Zhang H, DerMardirossian C, Kister J, Martinez L, Roush WR, Brown SJ, Bokoch GM, Rosen H: A novel and specific NADPH oxidase-1 (Nox1) small-molecule inhibitor blocks the formation of functional invadopodia in human colon cancer cells. ACS Chem Biol 2010;5:981-993.

64 Heumuller S, Wind S, Barbosa-Sicard E, Schmidt HH, Busse R, Schroder K, Brandes RP: Apocynin is not an inhibitor of vascular NADPH oxidases but an antioxidant. Hypertension 2008;51:211-217.

65 Li Y, Trush MA: Diphenyleneiodonium, an NAD(P)H oxidase inhibitor, also potently inhibits mitochondrial reactive oxygen species production. Biochem Biophys Res Commun 1998;253:295-299.

66 McCann SK, Roulston CL: NADPH Oxidase as a Therapeutic Target for Neuroprotection against Ischaemic Stroke: Future Perspectives. Brain Sci 2013;3:561-598.

67 Liu F, Ni W, Zhang J, Wang G, Li F, Ren W: Administration of Curcumin Protects Kidney Tubules Against Renal Ischemia-Reperfusion Injury (RIRI) by Modulating Nitric Oxide (NO) Signaling Pathway. Cell Physiol Biochem 2017;44:401-411.

68 Forstermann U, Munzel T: Endothelial nitric oxide synthase in vascular disease: from marvel to menace. Circulation 2006;113:1708-1714.

-69 Forstermann U, Sessa WC: Nitric oxide synthases: regulation and function. Eur Heart J 2012;33:829-837, 837a-837d.

70 Kubes P, Suzuki M, Granger DN: Nitric oxide: an endogenous modulator of leukocyte adhesion. Proc Natl Acad Sci U S A 1991;88:4651-4655.

71 Kurose I, Wolf R, Grisham MB, Granger DN: Modulation of ischemia/reperfusion-induced microvascular dysfunction by nitric oxide. Circ Res 1994;74:376-382.

72 Phillips L, Toledo AH, Lopez-Neblina F, Anaya-Prado R, Toledo-Pereyra LH: Nitric oxide mechanism of protection in ischemia and reperfusion injury. J Invest Surg 2009;22:46-55.

73 Alkaitis MS, Crabtree MJ: Recoupling the cardiac nitric oxide synthases: tetrahydrobiopterin synthesis and recycling. Curr Heart Fail Rep 2012;9:200-210.

74 Crabtree MJ, Channon KM: Synthesis and recycling of tetrahydrobiopterin in endothelial function and vascular disease. Nitric Oxide 2011;25:81-88.

75 Crabtree MJ, Tatham AL, Al-Wakeel Y, Warrick N, Hale AB, Cai S, Channon KM, Alp NJ: Quantitative regulation of intracellular endothelial nitric-oxide synthase (eNOS) coupling by both tetrahydrobiopterineNOS stoichiometry and biopterin redox status: insights from cells with tet-regulated GTP cyclohydrolase I expression. J Biol Chem 2009;284:1136-1144. 


\section{Cellular Physiology Cell Physiol Biochem 2018;46:1650-1667 \begin{tabular}{ll|l} 
and Biochemistry Published onlIne: Aprll 25, 2018 & $\begin{array}{l}\text { C } 2018 \text { The Author(s). Published by S. Karger AG, Basel } \\
\text { www.karger.com/cpb }\end{array}$ \\
\hline
\end{tabular}

76 Kietadisorn R, Juni RP, Moens AL: Tackling endothelial dysfunction by modulating NOS uncoupling: new insights into its pathogenesis and therapeutic possibilities. Am J Physiol Endocrinol Metab 2012;302:E481495.

77 Tatham AL, Crabtree MJ, Warrick N, Cai S, Alp NJ, Channon KM: GTP cyclohydrolase I expression, protein, and activity determine intracellular tetrahydrobiopterin levels, independent of GTP cyclohydrolase feedback regulatory protein expression. J Biol Chem 2009;284:13660-13668.

-78 Gottlieb RA: Cell death pathways in acute ischemia/reperfusion injury. J Cardiovasc Pharmacol Ther 2011;16:233-238.

79 Lopez-Neblina F, Toledo AH, Toledo-Pereyra LH: Molecular biology of apoptosis in ischemia and reperfusion. J Invest Surg 2005;18:335-350.

80 Ling Q Yu X, Wang T, Wang SG, Ye ZQ, Liu JH: Roles of the Exogenous H2S-Mediated SR-A Signaling Pathway in Renal Ischemia/ Reperfusion Injury in Regulating Endoplasmic Reticulum Stress-Induced Autophagy in a Rat Model. Cell Physiol Biochem 2017;41:2461-2474.

81 Zhu J, Yao K, Wang Q, Guo J, Shi H, Ma L, Liu H, Gao W, Zou Y, Ge J: Ischemic Postconditioning-Regulated miR-499 Protects the Rat Heart Against Ischemia/Reperfusion Injury by Inhibiting Apoptosis through PDCD4. Cell Physiol Biochem 2016;39:2364-2380.

82 Eefting F, Rensing B, Wigman J, Pannekoek WJ, Liu WM, Cramer MJ, Lips DJ, Doevendans PA: Role of apoptosis in reperfusion injury. Cardiovasc Res 2004;61:414-426.

83 McCully JD, Wakiyama H, Hsieh YJ, Jones M, Levitsky S: Differential contribution of necrosis and apoptosis in myocardial ischemia-reperfusion injury. Am J Physiol Heart Circ Physiol 2004;286:H1923-1935.

84 Kalogeris T, Bao Y, Korthuis RJ: Mitochondrial reactive oxygen species: A double edged sword in ischemia/ reperfusion vs preconditioning. Redox Biology 2014;2:702-714.

85 Liu H, Jing X, Dong A, Bai B, Wang H: Overexpression of TIMP3 Protects Against Cardiac Ischemia/ Reperfusion Injury by Inhibiting Myocardial Apoptosis Through ROS/Mapks Pathway. Cell Physiol Biochem 2017;44:1011-1023.

-86 Chen X, Zhang X, Xue L, Hao C, Liao W, Wan Q: Treatment with Enriched Environment Reduces Neuronal Apoptosis in the Periinfarct Cortex after Cerebral Ischemia/Reperfusion Injury. Cell Physiol Biochem 2017;41:1445-1456.

-87 Yu H, Zhang H, Zhao W, Guo L, Li X, Li Y, Zhang X, Sun Y: Gypenoside Protects against Myocardial IschemiaReperfusion Injury by Inhibiting Cardiomyocytes Apoptosis via Inhibition of CHOP Pathway and Activation of PI3K/Akt Pathway In vivo and In vitro. Cell Physiol Biochem 2016;39:123-136.

88 Di Lisa F, Bernardi P: Mitochondria and ischemia-reperfusion injury of the heart: fixing a hole. Cardiovasc Res 2006;70:191-199.

-89 Calo L, Dong Y, Kumar R, Przyklenk K, Sanderson TH: Mitochondrial dynamics: an emerging paradigm in ischemia-reperfusion injury. Curr Pharm Des 2013;19:6848-6857.

90 Maneechote C, Palee S, Chattipakorn SC, Chattipakorn N: Roles of mitochondrial dynamics modulators in cardiac ischaemia/reperfusion injury. J Cell Mol Med 2017

-91 Zepeda R, Kuzmicic J, Parra V, Troncoso R, Pennanen C, Riquelme JA, Pedrozo Z, Chiong M, Sanchez G, Lavandero S: Drp1 loss-of-function reduces cardiomyocyte oxygen dependence protecting the heart from ischemia-reperfusion injury. J Cardiovasc Pharmacol 2014;63:477-487.

\$2 Karbowski M, Lee YJ, Gaume B, Jeong SY, Frank S, Nechushtan A, Santel A, Fuller M, Smith CL, Youle RJ: Spatial and temporal association of Bax with mitochondrial fission sites, Drp1, and Mfn2 during apoptosis. J Cell Biol 2002;159:931-938.

-93 Sugioka R, Shimizu S, Tsujimoto Y: Fzo1, a protein involved in mitochondrial fusion, inhibits apoptosis. J Biol Chem 2004;279:52726-52734.

-94 Cipolat S, Rudka T, Hartmann D, Costa V, Serneels L, Craessaerts K, Metzger K, Frezza C, Annaert W, D’Adamio L, Derks C, Dejaegere T, Pellegrini L, D’Hooge R, Scorrano L, De Strooper B: Mitochondrial rhomboid PARL regulates cytochrome c release during apoptosis via OPA1-dependent cristae remodeling. Cell 2006;126:163-175.

-95 Saeed WK, Jun DW, Jang K, Chae YJ, Lee JS, Kang HT: Does necroptosis have a crucial role in hepatic ischemia-reperfusion injury? PLoS One 2017;12:e0184752.

-96 Kim CR, Kim JH, Park HL, Park CK: Ischemia Reperfusion Injury Triggers TNFalpha Induced-Necroptosis in 


\section{Cellular Physiology Cell Physiol Biochem 2018;46:1650-1667 \begin{tabular}{ll|l} 
and Biochemistry & $\begin{array}{l}\text { Dublished online: April 25, } 2018 \\
\text { Puld } 2018 \text { The Author(s). Published by S. Karger AG, Basel } \\
\text { www.karger.com/cpb }\end{array}$ \\
\hline
\end{tabular}}

Rat Retina. Curr Eye Res 2017;42:771-779.

97 Linkermann A, Hackl MJ, Kunzendorf U, Walczak H, Krautwald S, Jevnikar AM: Necroptosis in immunity and ischemia-reperfusion injury. Am J Transplant 2013;13:2797-2804.

-98 Newton K, Dugger DL, Maltzman A, Greve JM, Hedehus M, Martin-McNulty B, Carano RA, Cao TC, van Bruggen N, Bernstein L, Lee WP, Wu X, DeVoss J, Zhang J, Jeet S, Peng I, McKenzie BS, Roose-Girma M, Caplazi P, Diehl L, Webster JD, Vucic D: RIPK3 deficiency or catalytically inactive RIPK1 provides greater benefit than MLKL deficiency in mouse models of inflammation and tissue injury. Cell Death Differ 2016;23:1565-1576.

-99 Hoehn RS, Seitz AP, Jernigan PL, Gulbins E, Edwards MJ: Ischemia/Reperfusion Injury Alters Sphingolipid Metabolism in the Gut. Cell Physiol Biochem 2016;39:1262-1270.

100 Vanlangenakker N, Vanden Berghe T, Krysko DV, Festjens N, Vandenabeele P: Molecular mechanisms and pathophysiology of necrotic cell death. Curr Mol Med 2008;8:207-220.

101 Jing N, Fang B, Wang ZL, Ma H: Remote Ischemia Preconditioning Attenuates Blood-Spinal Cord Barrier Breakdown in Rats Undergoing Spinal Cord Ischemia Reperfusion Injury: Associated with Activation and Upregulation of CB1 and CB2 Receptors. Cell Physiol Biochem 2017;43:2516-2524.

102 Wong WW, Gentle IE, Nachbur U, Anderton H, Vaux DL, Silke J: RIPK1 is not essential for TNFR1-induced activation of NF-kappaB. Cell death and differentiation 2010;17:482-487.

103 Vanden Berghe T, Vanlangenakker N, Parthoens E, Deckers W, Devos M, Festjens N, Guerin CJ, Brunk UT, Declercq W, Vandenabeele P: Necroptosis, necrosis and secondary necrosis converge on similar cellular disintegration features. Cell Death Differ 2010;17:922-930.

104 Li CJ, Liao WT, Wu MY, Chu PY: New Insights into the Role of Autophagy in Tumor Immune Microenvironment. Int J Mol Sci 2017;18

105 Ma S, Wang Y, Chen Y, Cao F: The role of the autophagy in myocardial ischemia/reperfusion injury. Biochim Biophys Acta 2015;1852:271-276.

106 Gustafsson AB, Gottlieb RA: Eat your heart out: Role of autophagy in myocardial ischemia/reperfusion. Autophagy 2008;4:416-421.

107 Decuypere JP, Ceulemans LJ, Agostinis P, Monbaliu D, Naesens M, Pirenne J, Jochmans I: Autophagy and the Kidney: Implications for Ischemia-Reperfusion Injury and Therapy. Am J Kidney Dis 2015;66:699-709.

108 Gao Y, Yang H, Chi J, Xu Q Zhao L, Yang W, Liu W: Hydrogen Gas Attenuates Myocardial Ischemia Reperfusion Injury Independent of Postconditioning in Rats by Attenuating Endoplasmic Reticulum StressInduced Autophagy. Cell Physiol Biochem 2017;43:1503-1514.

109 Zhu S, Xu T, Luo Y, Zhang Y, Xuan H, Ma Y, Pan D, Li D, Zhu H: Luteolin Enhances Sarcoplasmic Reticulum Ca2+-ATPase Activity through p38 MAPK Signaling thus Improving Rat Cardiac Function after Ischemia/ Reperfusion. Cell Physiol Biochem 2017;41:999-1010.

110 Shu L, Zhang W, Huang C, Huang G, Su G: Troxerutin Protects Against Myocardial Ischemia/Reperfusion Injury Via Pi3k/Akt Pathway in Rats. Cell Physiol Biochem 2017;44:1939-1948.

-111 Zeng Q, Fu Q, Wang X, Zhao Y, Liu H, Li Z, Li F: Protective Effects of Sonic Hedgehog Against Ischemia/ Reperfusion Injury in Mouse Skeletal Muscle via AKT/mTOR/p70S6K Signaling. Cell Physiol Biochem 2017;43:1813-1828.

112 Qin J, Zhou J, Dai X, Zhou H, Pan X, Wang X, Zhang F, Rao J, Lu L: Short-term starvation attenuates liver ischemia-reperfusion injury (IRI) by Sirt1-autophagy signaling in mice. Am J Transl Res 2016;8:3364-3375.

113 Liu A, Huang L, Guo E, Li R, Yang J, Li A, Yang Y, Liu S, Hu J, Jiang X, Dirsch O, Dahmen U, Sun J: Baicalein pretreatment reduces liver ischemia/reperfusion injury via induction of autophagy in rats. Sci Rep 2016;6:25042.

114 Yamazaki S, Fujibayashi Y, Rajagopalan RE, Meerbaum S, Corday E: Effects of staged versus sudden reperfusion after acute coronary occlusion in the dog. J Am Coll Cardiol 1986;7:564-572.

115 Tong G, Zhang B, Zhou X, Zhao J, Sun Z, Tao Y, Pei J, Zhang W: Kappa-Opioid Agonist U50, 488H-Mediated Protection Against Heart Failure Following Myocardial Ischemia/Reperfusion: Dual Roles of Heme Oxygenase-1. Cell Physiol Biochem 2016;39:2158-2172.

116 Wu H, Wang Y, Wu C, Yang P, Li H, Li Z: Resveratrol Induces Cancer Cell Apoptosis through MiR-326/PKM2Mediated ER Stress and Mitochondrial Fission. J Agric Food Chem 2016;64:9356-9367.

117 Chen C, Chen W, Nong Z, Ma Y, Qiu S, Wu G: Cardioprotective Effects of Combined Therapy with Hyperbaric Oxygen and Diltiazem Pretreatment on Myocardial Ischemia-Reperfusion Injury in Rats. Cell Physiol Biochem 2016;38:2015-2029. 


\section{Cellular Physiology Cell Physiol Biochem 2018;46:1650-1667 \begin{tabular}{l|l} 
DOI: 10.1159/000489241 & $\begin{array}{l}\text { O 2018 The Author(s). Published by S. Karger AG, Basel } \\
\text { www.karger.com/cpb }\end{array}$ \\
\hline
\end{tabular}

118 Xu Z, Yu J, Wu J, Qi F, Wang H, Wang Z: The Effects of Two Anesthetics, Propofol and Sevoflurane, on Liver Ischemia/Reperfusion Injury. Cell Physiol Biochem 2016;38:1631-1642.

119 Peralta C, Prats N, Xaus C, Gelpi E, Rosello-Catafau J: Protective effect of liver ischemic preconditioning on liver and lung injury induced by hepatic ischemia-reperfusion in the rat. Hepatology 1999;30:1481-1489.

120 Lang J, Li W, Meng Z, Liu Y, Patel R: The protective effect of nitrite on liver ischemia reperfusion injury during transplantation. 2009.

121 Bice JS, Jones BR, Chamberlain GR, Baxter GF: Nitric oxide treatments as adjuncts to reperfusion in acute myocardial infarction: a systematic review of experimental and clinical studies. Basic Res Cardiol 2016;111

-122 Hataishi R, Rodrigues AC, Neilan TG, Morgan JG, Buys E, Shiva S, Tambouret R, Jassal DS, Raher MJ, Furutani E, Ichinose F, Gladwin MT, Rosenzweig A, Zapol WM, Picard MH, Bloch KD, Scherrer-Crosbie M: Inhaled nitric oxide decreases infarction size and improves left ventricular function in a murine model of myocardial ischemia-reperfusion injury. Am J Physiol Heart Circ Physiol 2006;291:H379-384.

123 Liu X, Huang Y, Pokreisz P, Vermeersch P, Marsboom G, Swinnen M, Verbeken E, Santos J, Pellens M, Gillijns $\mathrm{H}$, Van de Werf F, Bloch KD, Janssens S: Nitric oxide inhalation improves microvascular flow and decreases infarction size after myocardial ischemia and reperfusion. J Am Coll Cardiol 2007;50:808-817.

124 Nagasaka Y, Buys ES, Spagnolli E, Steinbicker AU, Hayton SR, Rauwerdink KM, Brouckaert P, Zapol WM, Bloch KD: Soluble guanylate cyclase-alpha1 is required for the cardioprotective effects of inhaled nitric oxide. Am J Physiol Heart Circ Physiol 2011;300:H1477-1483.

-125 Al-Herz W, Babiker F: Acute Intravenous Infusion of Immunoglobulins Protects Against Myocardial Ischemia-Reperfusion Injury Through Inhibition of Caspase-3. Cell Physiol Biochem 2017;42:2295-2306.

126 Shinbo T, Kokubo K, Sato Y, Hagiri S, Hataishi R, Hirose M, Kobayashi H: Breathing nitric oxide plus hydrogen gas reduces ischemia-reperfusion injury and nitrotyrosine production in murine heart. Am J Physiol Heart Circ Physiol 2013;305:H542-550.

127 Neye N, Enigk F, Shiva S, Habazettl H, Plesnila N, Kuppe H, Gladwin MT, Kuebler WM: Inhalation of NO during myocardial ischemia reduces infarct size and improves cardiac function. Intensive Care Med 2012;38:1381-1391.

128 Matsui N, Kasajima K, Hada M, Nagata T, Senga N, Yasui Y, Fukuishi N, Akagi M: Inhibiton of NF-kappaB activation during ischemia reduces hepatic ischemia/reperfusion injury in rats. J Toxicol Sci 2005;30:103110.

129 Chekeni FB, Elliott MR, Sandilos JK, Walk SF, Kinchen JM, Lazarowski ER, Armstrong AJ, Penuela S, Laird DW, Salvesen GS, Isakson BE, Bayliss DA, Ravichandran KS: Pannexin 1 channels mediate 'find-me' signal release and membrane permeability during apoptosis. Nature 2010;467:863-867.

130 Chen CB, Liu LS, Zhou J, Wang XP, Han M, Jiao XY, He XS, Yuan XP: Up-Regulation of HMGB1 Exacerbates Renal Ischemia-Reperfusion Injury by Stimulating Inflammatory and Immune Responses through the TLR4 Signaling Pathway in Mice. Cell Physiol Biochem 2017;41:2447-2460.

131 Xu S, Cherok E, Das S, Li S, Roelofs BA, Ge SX, Polster BM, Boyman L, Lederer WJ, Wang C, Karbowski M: Mitochondrial E3 ubiquitin ligase MARCH5 controls mitochondrial fission and cell sensitivity to stressinduced apoptosis through regulation of MiD49 protein. Mol Biol Cell 2016;27:349-359.

132 Hotchkiss RS, Strasser A, McDunn JE, Swanson PE: Cell death. N Engl J Med 2009;361:1570-1583.

133 Wood KC, Gladwin MT: The hydrogen highway to reperfusion therapy. Nat Med 2007;13:673-674.

134 Nauta RJ, Tsimoyiannis E, Uribe M, Walsh DB, Miller D, Butterfield A: The role of calcium ions and calcium channel entry blockers in experimental ischemia-reperfusion-induced liver injury. Ann Surg 1991;213:137142.

135 Roseborough G, Gao D, Chen L, Trush MA, Zhou S, Williams GM, Wei C: The mitochondrial K-ATP channel opener, diazoxide, prevents ischemia-reperfusion injury in the rabbit spinal cord. Am J Pathol 2006;168:1443-1451.

136 Lv Y, Ren Y, Sun L, Wang S, Wei M, Jia D: Protective effect of Na(+)/Ca (2+) exchange blocker KB-R7943 on myocardial ischemia-reperfusion injury in hypercholesterolemic rats. Cell Biochem Biophys 2013;66:357363. 